DOI: $10.19195 / 0137-1134.113 .8$

\author{
ARIEL PRZYBYŁOWICZ \\ Uniwersytet Wrocławski
}

\title{
WYKONAWCY WSPÓLNIE REALIZUJĄCY ZAMÓWIENIE PUBLICZNE A ART. 8 UST. 2A USTAWY Z DNIA 13 PAŹDZIERNIKA 1998 R. O SYSTEMIE UBEZPIECZEŃ SPOŁECZNYCH ${ }^{1}$
}

\begin{abstract}
Abstrakt: Artykuł 8 ust. 2a ustawy z dnia 13 października 1998 r. o systemie ubezpieczeń społecznych ustanawia na gruncie ubezpieczeń społecznych tak zwaną rozszerzoną definicję pracownika. Do celów ubezpieczeń społecznych jest nim też osoba, która zawarła umowę cywilnoprawną z własnym pracodawcą lub z innym podmiotem, lecz wykonuje ją na rzecz własnego pracodawcy. Przepis ten stwarza istotne problemy praktyczne, między innymi na gruncie zamówień publicznych. Jedną z problematycznych kwestii jest zatrudnianie tych samych osób przez kilku wykonawców wspólnie realizujących zamówienie publiczne jako konsorcjum. Pojawia się w wówczas pytanie, czy praca świadczona na podstawie umowy cywilnoprawnej zawartej z jednym z takich wykonawców, obok umowy o pracę zawartej z innym wykonawcą, stanowi tytuł ubezpieczenia w rozumieniu powołanego przepisu. W artykule autor przedstawia potencjalne konfiguracje takiego zatrudnienia i próbuje udzielić odpowiedzi na pytanie, w których z tych konfiguracji zasadne jest zastosowanie konstrukcji art. 8 ust. 2a ustawy o systemie ubezpieczeń społecznych. Automatyczne jej stosowanie w każdej takiej sytuacji jest bowiem w jego ocenie niedopuszczalne.
\end{abstract}

Słowa kluczowe: pracodawca, pracownik, zleceniobiorca, uznanie za pracownika, wykonawcy wspólnie realizujący zamówienie publiczne, ubezpieczenie społeczne

\section{WPROWADZENIE}

Rynek zamówień publicznych jest ważnym elementem gospodarki wolnorynkowej. W Polsce w roku 2016 jego wartość oszacowano na 107,4 mld zł, co stanowiło 5,8\% produktu krajowego brutto ${ }^{2}$. System zamówień publicznych podlega szczególnej regulacji prawnej, wykazującej istotne odmienności od powszechnego obrotu cywilnoprawnego. Dotyczy to w szczególności etapu kontraktowania, czyli

1 Tekst jedn. Dz.U. z 2017 r. poz. 1778, ze zm. (dalej: u.s.u.s.).

2 Sprawozdanie Prezesa Urzędu Zamówień Publicznych o funkcjonowaniu systemu zamówień publicznych w 2016 r., Warszawa 2017, s. 35, https://www.uzp.gov.pl/__data/assets/pdf_ file/0024/35178/Sprawozdanie-UZP-za-2016.pdf (dostęp: 31.01.2018). 
zawierania umów o udzielenie zamówienia publicznego ${ }^{3}$, głównie w zakresie wyboru wykonawcy, z którym umowa taka zostania zawarta. Takie szczególne traktowanie rynku zamówień publicznych nie powinno dziwić, skoro wydatkowane pieniądze są środkami publicznymi, które powinny być wydatkowane w sposób racjonalny i efektywny ${ }^{4}$. Regulacja prawna musi zatem gwarantować transparentny i zgodny z zasadami wolnej konkurencji dostęp do tego rynku. Na gruncie prawa polskiego podstawowym aktem prawnym regulującym zasady udzielania zamówień publicznych i ich realizacji, a także środki ochrony prawnej przysługujące wykonawcom, jest ustawa z dnia 29 stycznia 2004 r. Prawo zamówień publicznych $^{5}$. Implementuje ona w tym zakresie przepisy prawa unijnego ${ }^{6}$.

W przypadkach skomplikowanych i kosztownych zamówień potencjał ekonomiczny, techniczny czy osobowy jednego wykonawcy mógłby nie pozwalać na uzyskanie zamówienia, co mogłoby skutkować tym, że o istotne, kosztowne (ale zarazem zyskowne) zamówienia ubiegałyby się wyłącznie największe podmioty. Rodziłoby to ryzyko monopolizacji poszczególnych branż na rynku zamówień publicznych, a w konsekwencji również wzrostu cen. $Z$ tego między innymi powodu obowiązujące przepisy zezwalają na to, aby o udzielenie zamówienia publicznego ubiegać się mogli wspólnie działający wykonawcy. Łącząc swój potencjał, spełniać będą oni warunki stawiane przez zamawiających, których to warunków nie spełnialiby samodzielnie. Takie rozwiązanie przewiduje również u.p.z.p., w art. 23 ust. 1 stanowiąca, że wykonawcy mogą wspólnie ubiegać się o udzielenie zamówienia.

Opisana możliwość sprawia, że częstym przypadkiem jest realizowanie zamówienia publicznego przez kilku wykonawców, którzy wspólnie ubiegali się o jego udzielenie. O ile na gruncie prawa zamówień publicznych czy prawa cywilnego konstrukcja ta była i jest przedmiotem analiz, autor nie spotkał się do tej pory z jej analizą pod kątem prawa ubezpieczeń społecznych, w szczególności zaś w kontekście art. 8 ust. 2a u.s.u.s. Przepis ten zawiera autonomiczną definicję pojęcia pracodawcy na gruncie prawa ubezpieczeń społecznych, rozszerzając to pojęcie względem definicji zawartej w ustawie z dnia 26 czerwca 1974 r. Kodeks pracy ${ }^{7}$. Konstrukcja ta określana jest w literaturze jako uznanie za pracownika ${ }^{8}$. Niniejsze opracowanie ma na celu zasygnalizowanie problemów, jakie mogą występować w praktyce w sytuacji wspólnej realizacji zamówienia publicznego przez kilku wykonawców w kontekście art. 8 ust. 2a u.s.u.s. Autor podejmie również próbę

${ }^{3}$ G. Klich, Zmiana umowy w sprawie udzielenia zamówienia publicznego, Warszawa 2016, s. 1 .

4 M. Pużański, Prawo zamówień publicznych. Komentarz, Warszawa 2009, s. XIII.

5 Tekst jedn. Dz.U. z 2017 r. poz. 1579, ze zm. (dalej: u.p.z.p.).

6 Zob. też E.J. Nowicki, [w:] A. Bazan, E.J. Nowicki, Prawo zamówień publicznych. Komentarz, Warszawa 2015, SIP LEX.

7 Tekst jedn. Dz.U. z 2018 r. poz. 108, ze zm. (dalej: k.p.).

8 Np. I. Jędrasik-Jankowska, Konstrukcja uznania za pracownika w prawie ubezpieczenia społecznego, „Praca i Zabezpieczenie Społeczne” 2011, nr 8, s. 22 n. 
odpowiedzi na pytanie, czy w przypadku wykonywania przez pracowników jednego z takich wykonawców zadań objętych zamówieniem publicznym na podstawie umowy cywilnoprawnej zawartej z drugim wykonawcą (niepracodawcą) zasadne będzie za każdym razem zastosowanie konstrukcji uznania za pracownika.

\section{UWAGI TERMINOLOGICZNE}

Prawo zamówień publicznych nie posługuje się pojęciem wykonawców wspólnie realizujących zamówienie publiczne. Nie jest to zatem pojęcie języka prawnego. Na gruncie obowiązujących przepisów u.p.z.p. wykonawcą jest osoba fizyczna, osoba prawna albo jednostka organizacyjna nieposiadająca osobowości prawnej, która ubiega się o udzielenie zamówienia publicznego, złożyła ofertę lub zawarła umowę w sprawie zamówienia publicznego (art. 2 pkt 11 u.p.z.p.). Jak wskazano, u.p.z.p. zezwala wykonawcom wspólnie ubiegać się o udzielenie zamówienia, a zgodnie $\mathrm{z}$ art. 23 ust. 2 u.p.z.p. przepisy dotyczące wykonawcy stosuje się odpowiednio do wykonawców wspólnie ubiegających się o udzielenie zamówienia publicznego. Tym samym, choć ustawodawca nie posługuje się pojęciem wykonawców wspólnie realizujących zamówienie publiczne, na gruncie języka prawniczego zasadne jest przyjęcie takiego określenia względem podmiotów, które wspólnie ubiegały się o udzielenie zamówienia, a wskutek dokonania przez zamawiającego wyboru jako najkorzystniejszej oferty złożonej przez takich wykonawców, podpisały umowę udzielenia zamówienia. W praktyce, w celu wspólnego ubiegania się o zamówienie publiczne i następnie realizacji uzyskanego zamówienia, wykonawcy zawierają zazwyczaj umowę nienazwaną ${ }^{9}$, w języku prawniczym noszącą nazwę umowa konsorcjum lub umowa konsorcjalna ${ }^{10}$. Trzeba jednak zauważyć, że dopuszczając wspólne ubieganie się o udzielenie zamówienia, ustawodawca pozostawia daleko idącą swobodę wyboru formy prawnej tej wspólności ${ }^{11}$.

Najbardziej ogólnie konsorcjum można zdefiniować jako formę organizacyjną kooperacji gospodarczej — formę współpracy dwóch lub więcej podmiotów służącą realizacji pewnego wspólnego przedsięwzięcia gospodarczego ${ }^{12}$. Umowa konsorcjum określa wspólne przedsięwzięcie oraz reguluje zazwyczaj wzajemne prawa i obowiązki konsorcjantów, w kontekście zaś zamówień publicznych

${ }^{9}$ M. Jaworska, M. Kordowina, Wspólne ubieganie się o udzielenie zamówienia, „Prawo Zamówień Publicznych" 2017, nr 11, SIP Legalis.

10 Więcej na ten temat zob. K. Muchowska-Zwara, Prawne problemy funkcjonowania konsorcjów uczestniczacych $w$ obrocie regulowanym przez Prawo zamówień publicznych, Warszawa 2015, SIP Legalis; też J. Lic, Konstrukcja umowy konsorcjum w zamówieniach publicznych, „Prawo Zamówień Publicznych" 2016, nr 4, s. 146-157.

11 A. Sołtysińska, G. Wicik, Kwalifikacja wykonawców wspólnie ubiegajacych się o zamówienie publiczne, „Prawo Zamówień Publicznych” 2017, nr 1, s. 15-16.

12 K. Muchowska-Zwara, op. cit. 
w szczególności podział zakresu prac niezbędnych do wykonania zamówienia i podział wynagrodzenia przewidzianego za realizację zamówienia, a także zasady odpowiedzialności konsorcjantów względem siebie. Strony umowy konsorcjum określane są mianem konsorcjantów. Ponadto jeden z nich zazwyczaj umocowany jest do reprezentowania całego konsorcjum względem zamawiającego (tak zwany lider konsorcjum) ${ }^{13}$. Dotyczy to konsorcjum określanego w literaturze jako scentralizowane konsorcjum wykonawcze ${ }^{14}$. W wyniku zawarcia takiej umowy nie powstaje osobny byt prawny mający zdolność prawną i zdolność do czynności prawnych, gdyż taką zdolność mają wyłącznie członkowie tworzący konsorcjum ${ }^{15}$. Warto tu zauważyć, że zawarcie takiej umowy niejednokrotnie będzie konieczne, albowiem zgodnie z art. 23 ust. 4 u.p.z.p., jeżeli oferta wykonawców wspólnie ubiegających się o udzielenie zamówienia została wybrana, zamawiający może żądać, przed zawarciem umowy w sprawie zamówienia publicznego, przedstawienia umowy regulującej współpracę tych wykonawców.

$\mathrm{Z}$ punktu widzenia dalszych rozważań istotny jest przepis art. 141 u.p.z.p. Przewiduje on solidarną odpowiedzialność konsorcjantów za wykonanie umowy i wniesienie zabezpieczenia należytego wykonania umowy w sprawie udzielenie zamówienia publicznego. Jest to odpowiedzialność solidarna bierna i wynika wprost $\mathrm{z}$ ustawy ${ }^{16}$. Takie rozwiązanie w najlepszy sposób zabezpiecza interesy zamawiającego, wydatkującego wszakże środki publiczne, gdyż względem niego każdy z konsorcjantów jest w pełni i samodzielnie odpowiedzialny za prawidłowe wykonanie całego zamówienia. Oznacza to, że stosunek wewnętrzny wynikający z umowy konsorcjum, zgodnie z którą w praktyce każdy z konsorcjantów odpowiada za należyte wykonanie przypisanej mu części zamówienia i ponosi względem pozostałych konsorcjantów pełną odpowiedzialność za ewentualne niewykonanie czy nienależyte jej wykonanie, z punktu widzenia zamawiającego nie ma znaczenia. Nie jest bowiem możliwe wyłączenie wynikającej z art. 141 ust. 1 u.p.z.p. solidarnej odpowiedzialności w umowie konsorcjum ani nawet w umowie o udzielenie zamówienia publicznego - jest to norma bezwzględnie obowiązują$\mathrm{ca}^{17}$. Ewentualne jej wyłączenie w umowie regulującej współpracę wykonawców będzie oceniane przez pryzmat art. $58 \S 1$ k.c. ${ }^{18}$, a zatem będzie nieważne jako czynność prawna sprzeczna z ustawą. Zasygnalizowana kwestia może wpływać na ocenę możliwości zastosowania art. 8 ust. 2a u.s.u.s.

13 Więcej J. Lic, op. cit., s. 153-154.

14 A. Mościcka, Charakter prawny umowy konsorcjum, „Monitor Zamówień Publicznych” 2016, nr 4, s. 43.

15 Ibidem.

16 I. Skubiszak-Kalinowska, [w:] I. Skubiszak-Kalinowska, E. Wiktorowska, Prawo zamówień publicznych. Komentarz, Warszawa 2017, SIP LEX.

17 P. Granecki, Prawo zamówień publicznych. Komentarz, Warszawa 2016, SIP Legalis.

18 R. Świstak, Konsorcjum w świetle prawa zamówień publicznych - polemika, „Przegląd Prawa Handlowego" 2007, nr 3, s. 41. 
II. POTENCJALNE RELACJE MIĘDZY WYKONAWCAMI WSPÓLNIE
REALIZUJACCYMI ZAMÓWIENIE PUBLICZNE (KONSORCJANTAMI)

Zgodnie z przepisami u.p.z.p. wykonawcą może być osobę fizyczna, osoba prawna albo jednostka organizacyjna nieposiadająca osobowości prawnej. Tym samym w skład konsorcjum mogą wchodzić podmioty o różnorakim statusie prawnym i w najróżniejszych konfiguracjach: mogą to być wyłącznie osoby fizyczne (najczęściej prowadzące działalność gospodarczą), handlowe spółki osobowe czy handlowe spółki kapitałowe. Zawierając umowę konsorcjum, mają one na celu wspólne zrealizowanie określonego celu gospodarczego - wykonanie zamówienia publicznego, aby osiągnąć określony zysk. W skład konsorcjum wchodzą często podmioty będące konkurentami na rynku właściwym, a „łączące siły” wyłącznie w celu uzyskania i realizacji danego zamówienia. Zazwyczaj są to podmioty niemające żadnych powiązań kapitałowych lub osobowych, to znaczy całkowicie od siebie niezależne. Nie ma jednak przeszkód natury prawnej, aby w skład konsorcjum wchodziły podmioty z sobą powiązane. Jako przykłady wskazać można dwie osoby fizyczne pozostające w określonym stosunku prawnorodzinnym, z których każda prowadzi działalność gospodarczą, spółki prawa handlowego powiązane kapitałowo (jedna ze spółek posiada udziały w drugiej spółce) lub osobowo (większość udziałów w obu spółkach posiada jeden podmiot lub w obu spółkach w skład organów zarządzających wchodzą te same osoby fizyczne). Zasygnalizowanie tego jest niezbędne, albowiem zdaniem autora kwestia wzajemnych relacji między konsorcjantami, to znaczy wskazanych powiązań osobowych lub kapitałowych, nie powinna pozostawać bez znaczenia dla oceny możliwości zastosowania konstrukcji uznania z pracownika. Ograniczone ramy opracowania nie pozwalają jednak na głębszą analizę kwestii wzajemnych powiązań konsorcjantów ${ }^{19}$.

\section{MOŻLIWE RELACJE MIĘDZY WYKONAWCAMI WSPÓLNIE REALIZUJĄCYMI ZAMÓWIENIE PUBLICZNE (KONSORCJANTAMI) A ICH PRACOWNIKAMI}

Przy realizacji zamówienia publicznego wykonawcy (w tym konsorcja) rzadko samodzielnie (to znaczy pracą własnych rąk) wykonują wszelkie wynikające z niego zobowiązania. Jest to możliwe tylko wówczas, gdy wykonawcą jest osoba fizyczna prowadząca działalność gospodarczą lub w skład konsorcjum wchodzą wyłącznie takie osoby. Jeżeli wykonawcą jest jednostka organizacyjna (posiadająca lub nieposiadająca osobowości prawnej), zamówienie jest w istocie wykony-

19 Na temat powiązań kapitałowych pracodawcy, także w kontekście art. 8 ust. 2a u.s.u.s., zob. więcej M. Raczkowski, Powiązania kapitałowe pracodawcy a stosunek pracy, „Państwo i Prawo” 2009, nr 3, s. 60 n. 
wane przez inne osoby — osoby zatrudnione przez poszczególnych wykonawców. Wówczas możliwych jest kilka podstawowych konfiguracji, które - co ważne z punktu widzenia niniejszego opracowania - mogą wpływać na sytuację prawną w zakresie prawa ubezpieczeń społecznych.

Przedstawione tu możliwe konfiguracje pozwolą w kolejnej części opracowania na dokonanie próby oceny, w których z nich dopuszczalne będzie zastosowanie art. 8 ust. 2a u.s.u.s.

a) Pierwsza konfiguracja polega na tym, że każdy z konsorcjantów przypisaną mu część zamówienia realizuje wyłącznie z wykorzystaniem własnych pracowników (lub osób wykonujących pracę na podstawie umów cywilnoprawnych). Pozostali konsorcjanci nie korzystają zatem w żadnym zakresie z pracy osób zatrudnianych przez danego konsorcjanta.

b) Konfiguracja druga również dotyczy tylko dwóch podmiotów — jednego z konsorcjantów i jego pracownika. Możliwa jest bowiem sytuacja, w której pracownik konsorcjanta uczestniczy w realizacji zamówienia publicznego przez tego konsorcjanta, jednak nie w ramach swoich obowiązków pracowniczych, ale wykonując czynności rodzajowo inne niż umówiony rodzaj pracy — na podstawie umowy cywilnoprawnej.

c) Trzecia konfiguracja polega na tym, że pracownik jednego z konsorcjantów (konsorcjant $\mathrm{X}$ ), w ramach swych obowiązków pracowniczych względem konsorcjanta X, wykonuje określone prace składające się na przedmiot zamówienia, jednocześnie jednak wykonuje określone prace składające się na przedmiot zamówienia na podstawie dodatkowej umowy cywilnoprawnej zawartej z innym konsorcjantem (konsorcjantem Y). Konfiguracja ta może dodatkowo wystąpić w dwóch podtypach. W pierwszym z nich praca wykonywana przez pracownika konsorcjanta X na podstawie umowy cywilnoprawnej zawartej z konsorcjantem $Y$ może być rodzajowo tożsama z rodzajem pracy świadczonej na podstawie umowy o pracę z konsorcjantem X. W drugim podtypie praca wykonywana przez pracownika konsorcjanta $\mathrm{X}$ na podstawie umowy cywilnoprawnej zawartej z konsorcjantem Y może być rodzajowo inna niż praca świadczona przez tego pracownika na rzecz konsorcjanta $X$.

d) Czwarta konfiguracja polega na tym, że pracownik wykonuje obowiązki pracownicze w ramach umowy o pracę zawartej z konsorcjantem X, nie biorąc udziału w realizacji przez konsorcjanta $\mathrm{X}$ umowy o udzielenie zamówienia publicznego. Jednocześnie pracownik ten może uczestniczyć w realizacji zamówienia publicznego na podstawie umowy cywilnoprawnej zawartej z konsorcjantem Y. Tak jak w konfiguracji trzeciej czynności realizowane w ramach umowy cywilnoprawnej mogą być rodzajowo tożsame z obowiązkami pracowniczymi wynikającymi $\mathrm{z}$ umowy o pracę $\mathrm{z}$ konsorcjantem $\mathrm{X}$ lub też mogą być one rodzajowo inne.

e) Piąta konfiguracja dotyczy sytuacji, w której pracownik uczestniczy w realizacji zamówienia, wykonując swoje obowiązki wynikające $\mathrm{z}$ umowy o pracę $\mathrm{z}$ konsorcjantem X, przy jednoczesnym świadczeniu usług na rzecz konsorcjan- 
ta Y na podstawie umowy cywilnoprawnej, której przedmiot nie obejmuje jednak żadnych czynności składających się na realizację przedmiotu zamówienia publicznego. Także w tym przypadku czynności realizowane w ramach umowy cywilnoprawnej mogą być rodzajowo tożsame z obowiązkami pracowniczymi wynikającymi z umowy o pracę z konsorcjantem X lub też mogą być one rodzajowo inne.

Przytoczone podstawowe konfiguracje nie są wszystkimi możliwymi, jakie mogą występować w praktyce. Konsorcjum może przecież się składać z większej liczby konsorcjantów, z których każdy może zawierać umowy cywilnoprawne z pracownikami pozostałych konsorcjantów. Do tego między konsorcjantami mogą zachodzić różne relacje osobowe lub kapitałowe, sygnalizowane wcześniej. Wszystkie te elementy mogą tworzyć niezwykle złożone stany faktyczne, które wymagają oceny z punktu widzenia prawa ubezpieczeń społecznych, w szczególności w celu ustalenia właściwych zasad podlegania tym ubezpieczeniom.

\section{ISTOTA KONSTRUKCJI UZNANIA ZA PRACOWNIKA (ART. 8 UST. 2A U.S.U.S.)}

Przed przejściem do dalszych rozważań niezbędne jest przypomnienie, na czym polega konstrukcja uznania za pracownika, wynikająca z przepisu art. 8 ust. 2a u.s.u.s. Zgodnie ze wskazanym przepisem za pracownika w rozumieniu u.s.u.s. uważa się nie tylko osobę pozostającą w stosunku pracy, ale także osobę wykonująca pracę na podstawie umowy agencyjnej, umowy-zlecenia lub innej umowy o świadczenie usług, do której zgodnie z kodeksem cywilnym stosuje się przepisy dotyczące zlecenia albo umowy o dzieło, jeżeli umowę taką zawarła $\mathrm{z}$ pracodawcą, $\mathrm{z}$ którym pozostaje $\mathrm{w}$ stosunku pracy, lub jeżeli $\mathrm{w}$ ramach takiej umowy wykonuje pracę na rzecz pracodawcy, z którym pozostaje w stosunku pracy. Przepis ten rozszerza zatem pojęcie pracownika dla celów ubezpieczeń społecznych poza sferę stosunku pracy ${ }^{20}$. Jego zaś istotą jest traktowanie w zakresie ubezpieczeń społecznych jako pracownika osoby, która zawarła z umowę cywilnoprawną $\mathrm{w}$ warunkach określonych $\mathrm{w}$ art. 8 ust. $2 \mathrm{a}$ u.s.u.s. ${ }^{21}$

Pierwsza część przepisu art. 8 ust. 2a u.s.u.s. zasadniczo nie budzi wątpliwości $^{22}$. Wynika z niej, że przymusem ubezpieczenia objęte są wszystkie wskazane w tym przepisie cywilnoprawne umowy o świadczenie usług zawarte z własnym

20 M. Gersdorf, Prawo zatrudnienia, Warszawa 2013, SIP LEX.

21 Z. Kubot, Uznanie za pracownika osoby prowadzacej pozarolnicza działalność, „Praca i Zabezpieczenie Społeczne" 2013, nr 11, s. 25.

22 P. Prusinowski, Obowiązek zapłaty składek a definicja pracownika w prawie ubezpieczeń społecznych, „Monitor Prawa Pracy” 2011, nr 6, s. 292. 
$\left(\right.$ macierzystym ${ }^{23}$ ) pracodawcą — bez względu na rzeczywiste przeznaczenie tych umów ${ }^{24}$. Bez znaczenia pozostaje także, jakiego rodzaju prace są wykonywane na podstawie poszczególnych umów, to znaczy czy są one rodzajowo tożsame ${ }^{25}$.

W praktyce znacznie bardziej problematyczna jest druga część przepisu. Dotyczy ona umów cywilnoprawnych zawartych z podmiotem innym niż macierzysty pracodawca, ale praca $w$ ramach tej umowy wykonywana jest na rzecz tego pracodawcy. Istota problemu sprowadza się do oceny, kiedy praca wykonywana jest „na rzecz” macierzystego pracodawcy. Słusznie zauważa się w literaturze, że zwrot ,na rzecz" ma tym przypadku inne znaczenie niż w języku prawnym, w którym działanie „na czyją rzecz” może odbywać się w wyniku istnienia określonej więzi prawnej (stosunku prawnego) ${ }^{26}$. I. Jędrasik-Jankowska wskazuje, że przepis ten zastosowanie powinien mieć $\mathrm{w}$ razie zaistnienia tak zwanego trójkąta umów, to znaczy umowy o pracę, umowy-zlecenia między pracownikiem a osobą trzecią i umowy o podwykonawstwo między pracodawcą a zleceniodawcą, przy czym pracodawca w wyniku umowy o podwykonawstwo przejmuje w ostatecznym rozrachunku rezultat pracy wykonywanej na rzecz zleceniodawcy ${ }^{27}$. Nie zawsze jednak występować będzie trójkąt umów, zwłaszcza w odniesieniu do konsorcjantów wspólnie realizujących zamówienie publiczne. Zasadniczo umowę konsorcjum trudno byłoby traktować jako umowę o podwykonawstwo we wskazanym rozumieniu - konsorcjanci pozostają tutaj w równorzędnej relacji względem zamawiającego, który korzysta „fizycznie” z wykonywanych przez nich prac. Trzeba więc ustalić, czy również w innych sytuacjach będzie możliwe uznanie, że praca jest wykonywana na rzecz macierzystego pracodawcy. Innymi słowy w jakich innych sytuacjach zasadne będzie przyjęcie, że rzeczywistym beneficjentem ${ }^{28}$ pracy wykonywanej w ramach umowy cywilnoprawnej na rzecz konsorcjanta, który nie jest jednocześnie pracodawcą danej osoby, jest tenże macierzysty pracodawca.

Odpowiedź na to pytanie ma doniosłe znaczenie praktyczne. Konsekwencją zastosowania omawianej konstrukcji jest przecież to, że na gruncie ubezpieczeń

23 A. Kijowski, Zakres swobody pracodawcy w korzystaniu z zatrudnia cywilnoprawnego, [w:] Prawo pracy a wyzwania XXI wieku. Księga jubileuszowa Profesora Tadeusza Zielińskiego, red. M. Matey-Tyrowicz, L. Nawacki, B. Wagner, Warszawa 2002, s. 218.

24 A. Reda-Ciszewska, Cywilnoprawne umowy o zatrudnienie w prawie ubezpieczeń społecznych, [w:] Współczesne problemy prawa emerytalnego, red. T. Bińczycka-Majewska, M. Włodarczyk, Warszawa 2015, SIP LEX.

${ }_{25}$ Zob. M. Szabłowska-Juckiewicz, Zasady podlegania ubezpieczeniom społecznym z tytułu umów cywilnoprawnych zawieranych z własnym pracodawca, [w:] Umowy cywilnoprawne w ubezpieczeniach społecznych, red. M. Szabłowska-Juckiewicz, M. Wałachowska, J. Wantoch-Rekowski, Warszawa 2015, s. 354.

${ }^{26}$ Tak np. S. Koczur, Beneficjent pracy jako kryterium objęcia systemem ubezpieczeń społecznych, „Monitor Prawa Pracy”2013, nr 7, s. 353; I. Jędrasik-Jankowska, Konstrukcja uznania..., s. 25.

27 I. Jędrasik-Jankowska, Konstrukcja uznania..., s. 25.

28 Zob. P. Prusinowski, Podmiotowe „rozdrobnienie” świadczenia pracy, [w:] Księga jubileuszowa Profesora Grzegorza Goździewicza. Tendencje rozwojowe indywidualnego i zbiorowego prawa pracy, red. M. Szabłowska-Juckiewicz, B. Rutkowska, A. Napiórkowska, Toruń 2017, s. 232. 
społecznych umowa cywilnoprawna zawarta z własnym pracodawcą lub nawet z osobą trzecią, ale będąca podstawą wykonania pracy na rzecz tego pracodawcy, będzie traktowana jako swoiste „przedłużenie” umowy o pracę - a zatem osoba wykonująca pracę na jej podstawie podlega ubezpieczeniom społecznym na takich samych zasadach jak pracownicy ${ }^{29}$. Celem wprowadzenia konstrukcji uznania za pracownika do u.s.u.s. było bowiem przeciwdziałanie sytuacjom dzielenia wynagrodzenia pracownika między umowę o pracę oraz umowę cywilnoprawną w celu uniknięcia opłacania składki na ubezpieczenie społeczne od części osiąganego wynagrodzenia ${ }^{30}$. Wskutek tego w podstawie wymiaru składek na ubezpieczenia emerytalne i rentowe uwzględniony zostanie również przychód z tej właśnie cywilnoprawnej umowy ${ }^{31}$. Potwierdza to treść art. 18 ust. 1a u.s.u.s. Oznacza to, że od wynagrodzenia należnego na podstawie umowy cywilnoprawnej należy odprowadzić nie tylko zaliczkę na podatek dochodowy i składkę na ubezpieczenie zdrowotne, lecz także składki na ubezpieczenia społeczne — również gdy wedle ogólnych reguł rozwiązywania zbiegów tytułów ubezpieczenia w postaci stosunku pracy (art. 6 ust. 1 pkt 1 u.s.u.s.) i umowy cywilnoprawnej (art. 6 ust. 1 pkt 4 u.s.u.s.) umowa cywilnoprawna nie stanowiłaby tytułu obowiązkowego ubezpieczenia emerytalnego i rentowych. Jest to o tyle istotne w praktyce, że to płatnik jest zobowiązany ustalić prawidłowo zasady podlegania ubezpieczeniom społecznym, ustalić wysokość podstawy wymiaru składki, obliczyć należne składki i odprowadzić je na rachunek bankowy Zakładu Ubezpieczeń Społecznych. Autor nie podejmuje tu próby analizy, który z podmiotów powinien być uznany za płatnika w przypadku zastosowania konstrukcji uznania za pracownika. Wystarczy jedynie wskazać, że zagadnienie to jest od pewnego czasu jednoznacznie rozstrzygnięte $\mathrm{w}$ orzecznictwie sądowym ${ }^{32}$, które za płatnika w odniesieniu też do umowy cywilnoprawnej uznaje macierzystego pracodawcę. Stanowisko to jest jednak mocno krytykowane w literaturze, w której wskazuje się, że płatnikiem składek od umów cywilnoprawnych wykonywanych na rzecz pracodawcy w rozumieniu art. 8 ust. 2a u.s.u.s. powinien być podmiot, z którym została zawarta umowa cywilnoprawna ${ }^{33}$. Co najmniej ze względów praktycznych stanowisko judykatury nie wydaje się w tym zakresie prawidłowe, jednak kwestia ta nie jest przedmiotem niniejszej analizy.

29 I. Jędrasik-Jankowska, Pojęcia i konstrukcje prawne ubezpieczenia społecznego, Warszawa 2012 , s. 52.

30 Ibidem, s. 54.

31 Zob. M. Zieleniecki, Problemy zakresu podmiotowego ubezpieczeń społecznych, [w:] Ubezpieczenia społeczne w 70-lecie istnienia ZUS, red. U. Jackowiak, A. Malaka, Wrocław 2004, s. 112.

32 Uchwała SN z dnia 2 września 2009 r., II UZP 6/09, OSNCP 2010, nr 4, poz. 46.

33 Przykładowo I. Jędrasik-Jankowska, Konstrukcja uznania..., s. 22-27; a szczegółowa dogmatyczna analiza przepisów w tym zakresie zwłaszcza Z. Kubot, Definicja płatnika składek, „Praca i Zabezpieczenie Społeczne” 2012, nr 6, s. 12 n.; oraz idem, Płatnik składek od własnych, a nie cudzych umów cywilnoprawnych, „Praca i Zabezpieczenie Społeczne” 2017, nr 4, s. 13 n. 


\section{MOŻLIWOŚĆ ZASTOSOWANIA KONSTRUKCJI UZNANIA \\ ZA PRACOWNIKA (ART. 8 UST. 2A USTAWY O SYSTEMIE UBEZPIECZEŃ SPOŁECZNYCH) WE WSKAZANYCH RELACJACH}

Poczynione uwagi umożliwiają przejście do dalszych analiz, w których z przytoczonych w punkcie IV opracowania konfiguracji zasadne i dopuszczalne będzie zastosowanie tejże konstrukcji.

Konfiguracja pierwsza (a) z punktu widzenia prawa ubezpieczeń społecznych wydaje się najmniej złożona. Skoro zatrudnieni wykonują pracę wyłącznie na rzecz jednego konsorcjanta, to nie ma jakichkolwiek przesłanek do zastosowania konstrukcji uznania za pracownika. Osoby te będą podlegać ubezpieczeniom społecznym zgodnie z przepisami u.s.u.s. jako pracownicy (art. 6 ust. 1 pkt 1 u.s.u.s.) lub jako tak zwani zleceniobiorcy (art. 6 ust. 1 pkt 4 u.s.u.s.) w wypadku wykonywania pracy na podstawie umowy agencyjnej lub umowy zlecenia albo innej umowy o świadczenie usług, do której zgodnie z kodeksem cywilnym stosuje się przepisy dotyczące zlecenia. Zastosowanie znajdą wtedy ogólne zasady podlegania ubezpieczeniom, w tym ewentualnych zbiegów tytułów w przypadku zatrudnienia na podstawie kilku umów.

Druga konfiguracja (b) też nie budzi wątpliwości. Każda umowa cywilnoprawna zawarta z własnym pracodawcą będzie skutkować zastosowaniem art. 8 ust. 2a u.s.u.s. Przepis ten nie rozróżnia przy tym, czy umowa cywilnoprawna zawarta z własnym pracodawcą obejmuje takie same czy inne rodzajowo obowiązki niż wynikające z umowy o pracę. Warto jednak wskazać, że zawarcie z własnym pracodawcą umowy cywilnoprawnej obejmującej wykonywanie prac tożsamych z zakresem obowiązków wynikającym z umowy o pracę może zostać uznane za obejście przepisów prawa pracy dotyczących godzin nadliczbowych ${ }^{34}$, a także przepisów prawa ubezpieczeń społecznych, co skutkuje uznaniem takiej umowy za nieważną na podstawie art. $18 \S 2$ k.p. ${ }^{35} \mathrm{~W}$ konsekwencji obowiązki wykonywane w ramach takich umów są traktowane jak obowiązki realizowane w ramach (jednego) stosunku pracy, z wszystkimi tego konsekwencjami wynikającymi z przepisów prawa pracy i ubezpieczeń społecznych ${ }^{36}$.

Sytuacja jednak się komplikuje przy korzystaniu przez kilku konsorcjantów z pracy jednego pracownika, czyli w konfiguracjach trzeciej, czwartej i piątej.

Konfiguracja trzecia (c) polegała na tym, że w ramach obowiązków pracowniczych na podstawie umowy o pracę z konsorcjantem X pracownik wykonuje przedmiot zamówienia publicznego, jednocześnie na podstawie umowy cywilnoprawnej z konsorcjantem Y także uczestniczy w realizacji przedmiotu tego zamówienia. Przy czym w ramach umowy cywilnoprawnej może być wykonywana praca rodzajowo tożsama z pracą wykonywaną na podstawie umowy o pracę

34 Np. uchwała SN z dnia 12 kwietnia 1994 r., I PZP 13/94, OSNAPiUS 1994, nr 11, poz. 139.

35 Wyrok SN z dnia 16 grudnia 1998 r., II UKN 392/98, OSNAPiUS 2000, nr 4, poz. 157.

36 Por. B. Cudowski, Dodatkowe zatrudnienie, Warszawa 2007, SIP LEX. 
(podtyp I) lub też prace rodzajowo różne (podtyp II). Przy pracach rodzajowo różnych w ocenie autora art. 8 ust. $2 \mathrm{a}$ u.s.u.s. nie powinien znaleźć zastosowania. Wynika to $\mathrm{z}$ faktu, że powierzenie przez konsorcjanta Y takiej pracy w ramach umowy cywilnoprawnej konkretnej osobie nie ma związku z faktem jego zatrudnienia u konsorcjanta $X$, skoro czynności wykonywane w ramach poszczególnych umów są rodzajowo różne. Osoba ta posiadła określone umiejętności, kompetencje czy doświadczenie, których nie wykorzystuje w ramach obowiązków pracowniczych, ale zgodnie z zasadą wolności pracy ma prawo wykorzystywać poza stosunkiem pracy, w ramach dodatkowego zatrudnienia. W tym przypadku też ewentualne powiązania kapitałowe lub osobowe konsorcjantów X i Y nie powinny mieć znaczenia.

Inaczej sytuacja może się przedstawiać w podtypie pierwszym — gdy prace wykonywane w ramach umowy cywilnoprawnej zawartej z konsorcjantem Y są rodzajowo tożsame z pracami wykonywanymi na podstawie stosunku pracy z konsorcjantem X. W praktyce taki podział może bowiem oznaczać sztuczne rozbicie zadań pracowniczych między różne podmioty (tak zwana multiplikacja podmiotów zatrudniających, rozumiana jako rozdrobnienie stosunku zatrudnienia dotyczącego określonej osoby w celu wydzielenia poszczególnych jego fragmentów do odrębnego stosunku prawnego, który łączy zatrudnionego bądź z tym samym podmiotem, bądź z innym ${ }^{37}$ ), w szczególności w celu uniknięcia konieczności uiszczania składek na ubezpieczenia społeczne od pełnego wynagrodzenia za realizację tych zadań. Nie bez znaczenia jest również sygnalizowana już wcześniej kwestia obchodzenia przepisów prawa pracy, w szczególności w zakresie pracy w godzinach nadliczbowych. Takie sztuczne podzielenie zadania pracowniczego między dwa podmioty i dwie umowy (o pracę i cywilnoprawną) nie powinno mieć miejsca. W tej konfiguracji zastosowanie art. 8 ust. 2a u.s.u.s. będzie uzasadnione, wymaga to jednak wcześniejszego ustalenia, że podział zadania pracowniczego nie jest uzasadniony obiektywnymi przesłankami i ma na celu obniżenie kosztów realizacji zamówienia przez obniżenie kosztów zatrudnienia czy właśnie obejście przepisów prawa pracy. Mając na względzie praktykę, warto tu wskazać, że sam podział przedmiotu zamówienia między konsorcjantów w ramach umowy konsorcjum, polegający na przypisaniu określonych prac (na przykład kryterium miejsca wykonywania usług ochrony) danemu konsorcjantowi, nie będzie stanowił takiego obiektywnie uzasadnionego kryterium podziału zadania pracowniczego. Jest to jednak w każdym przypadku kwestia ustaleń faktycznych, których dokonać musi najpierw płatnik, a później Zakład Ubezpieczeń Społecznych czy wreszcie sąd. Kwestia powiązań kapitałowych lub osobowych konsorcjantów X i Y nie powinna pozostawać bez znaczenia - tego typu powiązania sprawiają, że konsorcjantom łatwiej dokonywać ustaleń dotyczących podziału przedmiotu zamówienia

37 A. Kurzych, Multiplikacja podmiotów zatrudniających a stosunki ubezpieczenia społecznego, [w:] Umowy cywilnoprawne w ubezpieczeniach..., s. 333. 
i swoistego wzajemnego dzielenia się swoimi pracownikami w celu optymalizacji kosztów działalności i zmniejszania kosztów realizacji zamówienia.

W przypadku konfiguracji czwartej (d) i piątej (e) konstrukcja uznania za pracownika zasadniczo nie powinna znaleźć zastosowania, choć nie można tego a priori w pełni wykluczyć. Chodzi o sytuacje, w których jedna osoba jest pracownikiem konsorcjanta $\mathrm{X}$ i wykonuje również prace na podstawie umowy cywilnoprawnej z konsorcjantem Y, przy czym zaangażowanie danej osoby w realizację zamówienia publicznego występuje wyłącznie w ramach realizacji obowiązków wynikających z umowy cywilnoprawnej (konfiguracja czwarta) lub wyłącznie z umowy o pracę (konfiguracja piąta). Przy różnych rodzajowo pracach wykonywanych na podstawie tych umów art. 8 ust. 2 a u.s.u.s. nie powinien znaleźć zastosowania z przyczyn już wskazanych.

Natomiast przy pracach tożsamych rodzajowo wydaje się to dopuszczalne w przypadku dokonania ustaleń faktycznych, że tego typu zatrudnienie jest stosowane w celu zmniejszenia kosztów zatrudnienia przez poszczególnych konsorcjantów. Nie można bowiem wykluczyć, że w ramach stosunku pracy osiągane jest minimalne wynagrodzenie, aby przy ogólnej regule zbiegu tytułów ubezpieczenia uniknąć konieczności odprowadzenia składki od pełnego wynagrodzenia. Zasadne może być wtedy uznanie, że strony zmierzały do sztucznego podzielenia zadań pracowniczych między różne podmioty (czyli nieuzasadnionej multiplikacji podmiotów zatrudniających). Jest to szczególnie możliwe w sytuacji istnienia powiązań kapitałowych lub osobowych poszczególnych konsorcjantów, zwłaszcza gdy masowo korzystają oni z takiej praktyki. Ocena ta wymaga jednak rzetelnego ustalenia stanu faktycznego i jego wnikliwej oceny.

Trzeba tu wskazać na dwie kwestie, które prima facie mogłyby przemawiać za uznaniem, że wszelka praca wykonywana przez daną osobę w ramach umowy cywilnoprawnej zawartej z konsorcjantem Y jest jednocześnie pracą wykonywaną na rzecz konsorcjanta X, czyli „macierzystego pracodawcy”. Pierwsza z nich dotyczy wynagrodzenia należnego konsorcjum jako całości za należyte wykonanie zamówienia publicznego. W praktyce wypłacane jest bowiem jedno wynagrodzenie, na podstawie jednej faktury VAT, wystawianej przez lidera konsorcjum. Wynagrodzenie przekazywane jest bezpośrednio liderowi konsorcjum, który następnie dokonuje jego podziału zgodnie z postanowieniami umowy konsorcjum. Ta zaś przewiduje, iż każdy z konsorcjantów otrzymuje wynagrodzenie proporcjonalne do zakresu pracy, który samodzielnie realizował. W ocenie autora tym samym nie sposób uznać uznać, że ekonomicznym beneficjentem pracy wykonywanej przez daną osobę na podstawie umowy cywilnoprawnej z konsorcjantem Y będzie również konsorcjant X, czyli macierzysty pracodawca tej osoby. Każdy konsorcjant otrzymuje wszakże wynagrodzenie za tę część prac, za którą był odpowiedzialny i którą wykonał własnym kosztem (między innymi ponosząc koszty w postaci wynagrodzenia wypłaconego za usługi wykonane przez swoich zleceniobiorców). 
Drugą ze wskazanych kwestii jest solidarne ponoszenie odpowiedzialności przez konsorcjantów względem zamawiającego za prawidłowe wykonanie zamówienia. Nienależyte wykonanie nawet części zamówienia przez jednego z konsorcjantów będzie bowiem skutkować negatywnymi konsekwencjami dla całego konsorcjum. Naprawienia szkody zamawiający będzie domagał się wszakże solidarnie od wszystkich konsorcjantów. W interesie każdego konsorcjanta jest, aby pozostali konsorcjanci należycie wykonali przypisaną im część zamówienia. Jeśli zatem konsorcjant $\mathrm{Y}$, korzystając na podstawie umowy cywilnoprawnej z pracy pracownika konsorcjanta $X$, nie wykona należycie swojej części zamówienia, konsekwencje poniesie również konsorcjant X. Mogłoby to prowadzić do konstatacji, że treść art. 141 u.p.z.p. przemawia za przyjęciem stanowiska, że każdy przypadek korzystania przez konsorcjanta $\mathrm{Y}$ z pracy pracownika konsorcjanta $\mathrm{X}$ będzie jednocześnie wykonywaniem przez zleceniobiorcę pracy na rzecz konsorcjanta X. Jeśli nie będzie on zasadniczo beneficjentem pracy w rozumieniu faktycznym (nie będzie korzystał bezpośrednio z efektów pracy wykonywanej w ramach umowy cywilnoprawnej), to osiąga on pewien zysk ekonomiczny wiążący się z prawidłowo wykonanym zamówieniem ${ }^{38}$. W ocenie autora takie rozumienie pomija jednak istotny fakt, jakim jest odmienne uregulowanie zasad odpowiedzialności w umowie konsorcjum. Zgodnie $\mathrm{z}$ doświadczeniem życiowym umowy konsorcjum zawsze zawierają regulację dotyczącą wzajemnych zasad odpowiedzialności konsorcjantów względem siebie i określają wprost, że każdy z konsorcjantów w relacji wewnętrznej ponosi pełną odpowiedzialność za należyte wykonanie przypisanej mu części zamówienia. Nawet zatem w razie pociągnięcia konsorcjantów do solidarnej odpowiedzialności w ostatecznym rozrachunku każdy z konsorcjantów ponosi wyłączną i pełną odpowiedzialność za swoje działania i zaniechania, albowiem konsorcjantom przysługiwać będą roszczenia regresowe względem nierzetelnego konsorcjanta. Tym samym przepis art. 141 u.p.z.p. nie może stanowić podstawy uznania, że praca wykonywania przez zleceniobiorcę w konfiguracji trzeciej samoistnie uzasadnia zastosowanie art. 8 ust. 2a u.s.u.s.

\section{WNIOSKI}

Artykuł 8 ust. 2a u.s.u.s. ma charakter wyjątku. Wprowadza wszakże wyjątek od pochodności ubezpieczenia od działalności (zatrudnienia) wybranej przez ubezpieczonego, a zatem nie może być interpretowany rozszerzająco, ale wyłącznie ściśle ${ }^{39}$. Wynika to wprost $\mathrm{z}$ podstawowych reguł wykładni prawa (exceptiones non sunt extendendae). Tym samym nieuzasadnione jest automatyczne stosowanie konstrukcji uznania za pracownika w każdym przypadku ustalenia, że jeden z kon-

38 Jak się zdaje, takie stanowisko prezentuje S. Koczur, op. cit., s. 353.

39 Z. Kubot, Uznanie za pracownika..., s. 26. 
sorcjantów korzysta na podstawie umowy cywilnoprawnej wskazanej w tym przepisie z usług pracownika innego konsorcjanta. Jako że pojęcie pracy wykonywanej „na rzecz” macierzystego pracodawcy odnosi się do sfery ustaleń faktycznych, należy w każdym przypadku takich umów ustalić przede wszystkim, czy prace wykonywane na podstawie obu umów wchodzą w zakres przedmiotu zamówienia i czy są tożsame rodzajowo, z uwzględnieniem powiązań osobowych lub kapitałowych zachodzących między konsorcjantami. Jeśli obie umowy są wykonywane w celu realizacji przez konsorcjum przedmiotu zamówienia, przy tożsamości rodzajowej wykonywanej pracy, z wysokim stopniem prawdopodobieństwa chodzi o sztuczny (to znaczy nieznajdujący obiektywnie uzasadnionych przyczyn) podział zadań pracowniczych w celu obejścia przepisów prawa pracy lub ubezpieczeń społecznych. Jeśli prace te są rodzajowo inne, konstrukcja uznania pracownika nie powinna zasadniczo znaleźć zastosowania; nie jest jednak wykluczona w szczególnych okolicznościach danego stanu faktycznego. Podobne wnioski odnoszą się do sytuacji, gdy tylko jedna z umów (o pracę lub cywilnoprawna) jest realizowana w ramach wykonywania przedmiotu zamówienia przez konsorcjantów. Jeżeli umowy dotyczą prac rodzajowo różnych, art. 8 ust. 2a u.s.u.s. nie powinien znaleźć zastosowania, natomiast dopuszczalne będzie jego zastosowania w razie ustalenia, że taka konstrukcja zatrudniania ma na celu zmniejszenie kosztów zatrudnienia, a tym samym realizacji samego zamówienia publicznego. Dokonanie prawidłowej oceny prawnej jest przy tym trudne i wymaga dokładnego ustalenia (często skomplikowanego) stanu faktycznego i wnikliwej jego analizy.

Ze względu na znacznie ograniczone ramy niniejsze opracowanie nie wyczerpuje całości zagadnienia. Przedstawione rozważania sygnalizują problemy stosowania konstrukcji uznania za pracownika i mają być przyczynkiem do dalszej dyskusji, wskazując jednocześnie możliwe kierunki poszukiwania odpowiedzi na pytanie, kiedy możliwe jest zastosowanie art. 8 ust. 2a u.s.u.s. w przypadku wykonawców wspólnie realizujących zamówienie publiczne. Rozważania te mogą również być pomocne odnośnie do innych konsorcjów wspólnie realizujących określone przedsięwzięcie gospodarcze poza rynkiem zamówień publicznych.

\section{CONTRACTORS JOINTLY IMPLEMENTING A PUBLIC CONTRACT AND ARTICLE 8 SEC. 2A OF THE ACT OF 13TH OF OCTOBER 1998 ON THE SOCIAL INSURANCE SYSTEM}

\section{Summary}

Article 8 para. 2a of the Act on the social insurance system includes the so-called extended employee definition. For social security purposes, it is also a person who has entered into a civil law contract with his own employer or with another entity, but performs this contract for his own employer. This provision creates significant practical problems, including the problems on the basis 
of public procurements. One of the problematic questions is employing of the same people by several contractors, who perform the public procurement together as a consortium. The question then arises whether the work performed on the basis of a civil law contract concluded with one of such contractors, next to the employment contract concluded with another contractor, constitutes the title of social insurance according to the mentioned provision. In the article the Author presents potential configurations of such employment and tries to answer the question, in which of those configurations is the Article 8 para. 2a of the Act on the social insurance system applicable. According to Author, its automatic application in all of those situations is unacceptable.

Keywords: employer, social insurance, contractor executing a public contract

\section{BIBLIOGRAFIA}

Cudowski B., Dodatkowe zatrudnienie, Warszawa 2007.

Gersdorf M., Prawo zatrudnienia, Warszawa 2013.

Granecki P., Prawo zamówień publicznych. Komentarz, Warszawa 2016.

Jaworska M., Kordowina M., Wspólne ubieganie się o udzielenie zamówienia, „Prawo Zamówień Publicznych" 2017, nr 11, SIP Legalis.

Jędrasik-Jankowska I., Konstrukcja uznania za pracownika w prawie ubezpieczenia społecznego, „Praca i Zabezpieczenie Społeczne” 2011, nr 8.

Jędrasik-Jankowska I., Pojęcia i konstrukcje prawne ubezpieczenia społecznego, Warszawa 2012.

Kijowski A., Zakres swobody pracodawcy w korzystaniu z zatrudnia cywilnoprawnego, [w:] Prawo pracy a wyzwania XXI wieku. Księga jubileuszowa Profesora Tadeusza Zielińskiego, red. M. Matey-Tyrowicz, L. Nawacki, B. Wagner, Warszawa 2002.

Klich G., Zmiana umowy w sprawie udzielenia zamówienia publicznego, Warszawa 2016.

Koczur S., Beneficjent pracy jako kryterium objęcia systemem ubezpieczeń społecznych, „Monitor Prawa Pracy" 2013, nr 7.

Kubot Z., Definicja płatnika składek, „Praca i Zabezpieczenie Społeczne” 2012, nr 6.

Kubot Z., Płatnik składek od własnych, a nie cudzych umów cywilnoprawnych, „Praca i Zabezpieczenie Społeczne" 2017, nr 4.

Kubot Z., Uznanie za pracownika osoby prowadzacej pozarolnicza działalność, „Praca i Zabezpieczenie Społeczne" 2013, nr 11.

Kurzych A., Multiplikacja podmiotów zatrudniających a stosunki ubezpieczenia społecznego, [w:] Umowy cywilnoprawne w ubezpieczeniach społecznych, red. M. Szabłowska-Juckiewicz, M. Wałachowska, J. Wantoc-Rekowski, Warszawa 2015.

Lic J., Konstrukcja umowy konsorcjum w zamówieniach publicznych, „Prawo Zamówień Publicznych" 2016, nr 4.

Mościcka A., Charakter prawny umowy konsorcjum, „Monitor Zamówień Publicznych” 2016, nr 4.

Muchowska-Zwara K., Prawne problemy funkcjonowania konsorcjów uczestniczacych w obrocie regulowanym przez Prawo zamówień publicznych, Warszawa 2015, SIP Legalis.

Nowicki E.J., [w:] A. Bazan, E.J. Nowicki, Prawo zamówień publicznych. Komentarz, Warszawa 2015.

Prusinowski P., Obowiązek zapłaty składek a definicja pracownika w prawie ubezpieczeń społecznych, „Monitor Prawa Pracy” 2011, nr 6.

Prusinowski P., Podmiotowe „rozdrobnienie” świadczenia pracy, [w:] Księga jubileuszowa Profesora Grzegorza Goździewicza. Tendencje rozwojowe indywidualnego i zbiorowego prawa pracy, red. M. Szabłowska-Juckiewicz, B. Rutkowska, A. Napiórkowska, Toruń 2017. 
Pużański M., Prawo zamówień publicznych. Komentarz, Warszawa 2009.

Raczkowski M., Powiazania kapitałowe pracodawcy a stosunek pracy, „Państwo i Prawo” 2009, nr 3.

Reda-Ciszewska A., Cywilnoprawne umowy o zatrudnienie w prawie ubezpieczeń społecznych, [w:] Współczesne problemy prawa emerytalnego, red. T. Bińczycka-Majewska, M. Włodarczyk, Warszawa 2015.

Skubiszak-Kalinowska I., [w:] I. Skubiszak-Kalinowska, E. Wiktorowska, Prawo zamówień publicznych. Komentarz, Warszawa 2017.

Sołtysińska A., Wicik G., Kwalifikacja wykonawców wspólnie ubiegających się o zamówienie publiczne, „Prawo Zamówień Publicznych” 2017, nr 1.

Szabłowska-Juckiewicz M., Zasady podlegania ubezpieczeniom społecznym z tytułu umów cywilnoprawnych zawieranych $z$ wlasnym pracodawca, [w:] Umowy cywilnoprawne $w$ ubezpieczeniach społecznych, red. M. Szabłowska-Juckiewicz, M. Wałachowska, J. Wantoch-Rekowski, Warszawa 2015.

Świstak R., Konsorcjum w świetle prawa zamówień publicznych - polemika, „Przegląd Prawa Handlowego" 2007, nr 3.

Zieleniecki M., Problemy zakresu podmiotowego ubezpieczeń społecznych, [w:] Ubezpieczenia społeczne w 70-lecie istnienia ZUS, red. U. Jackowiak, A. Malaka, Wrocław 2004. 